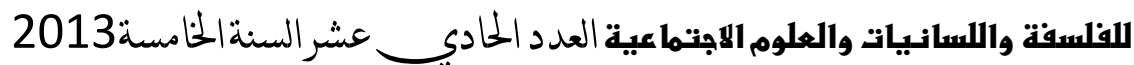

\title{
צורות ההתרפקות הנוסטאלגית על ימי היישוב הישן
}

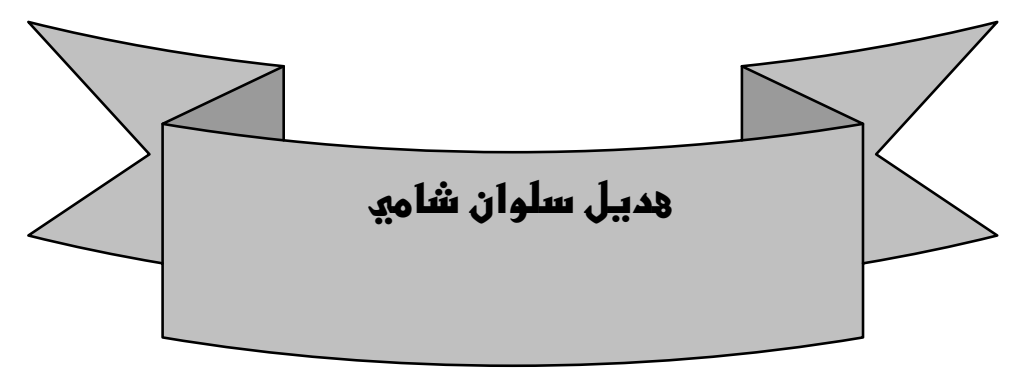

\section{צורות ההתרפקות הנוסטאלגית על ימי היישוב הישן}

\section{בספרות העברית החדשה}

\section{מחלקת השפה העברית}

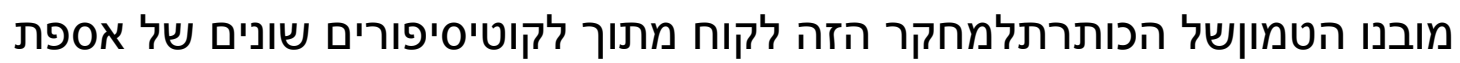

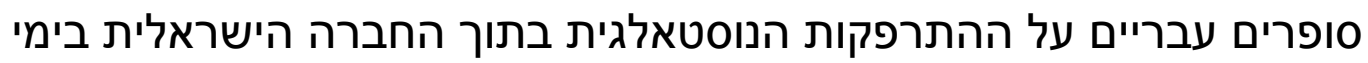

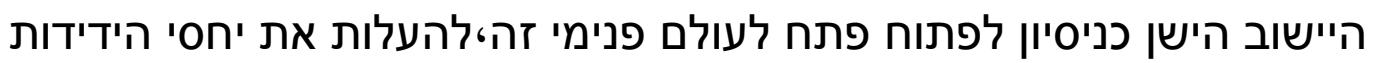

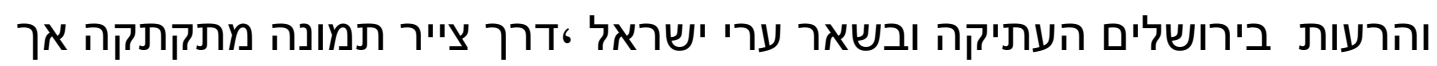

חיצונית תלויה במסגרת השאלות הלאומיות (1)

אילו לא חרגו ממסגרת הלבטים המחשבתיים לגבי יושביה האחרים של ארץזום

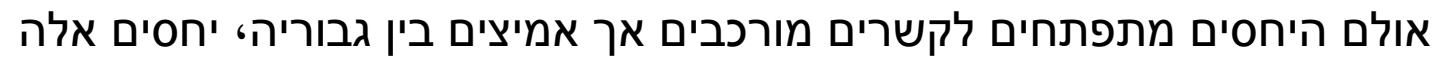

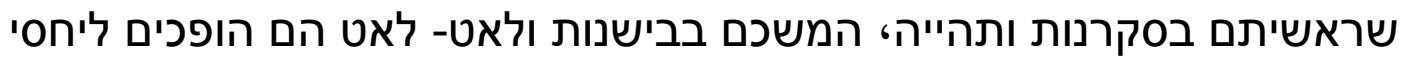

קירבה וידידות טובה ועזרה הדדי'(2)

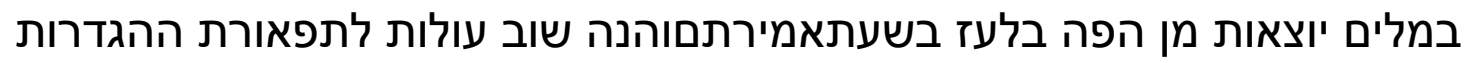

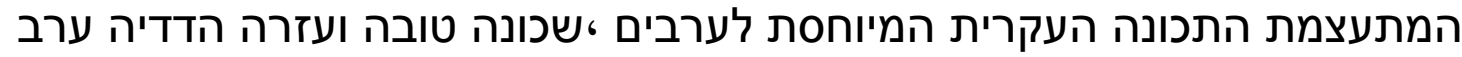

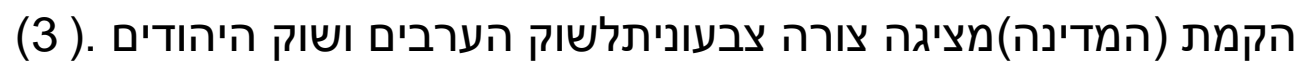

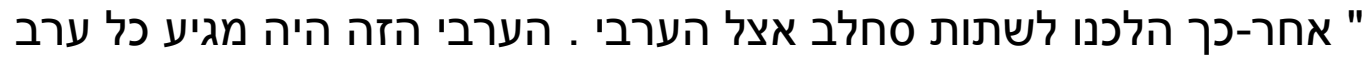

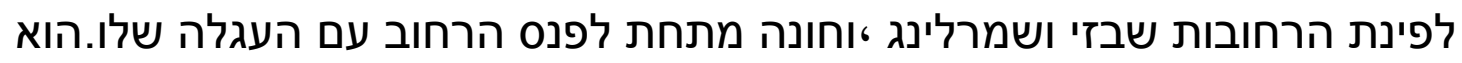

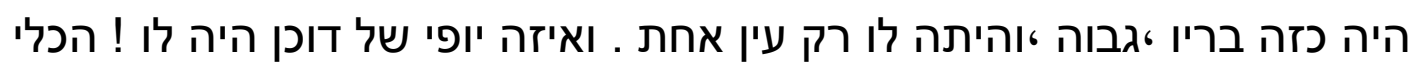


שבו היה מנחושת • וגחלים בוערות מתחתיו .ומגש גדול עם רגליים • מסביבו

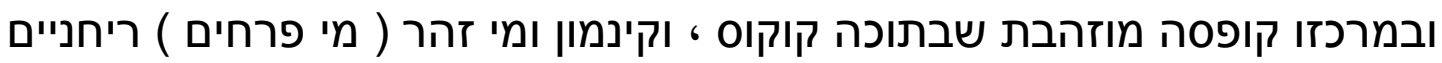

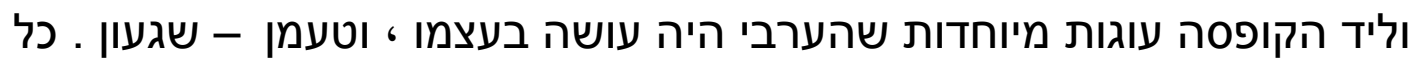
ערב היינו מתאספים סביבו ، ושותים כל אחד כוס סחלב ، עם קוקוס וקינמון ומי

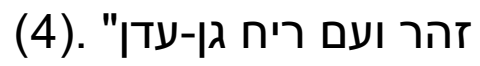

תיאור צבעוני זה של מוכר הסחלב ומטעמיו • הלקוח מתוך ספרו של יוסף אוחנה

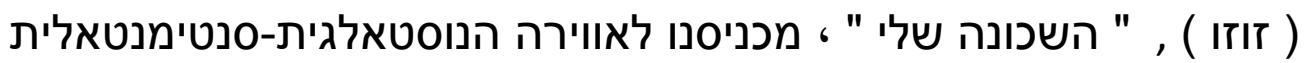
המאפיינת טיפולם של שורת ספרי-ילדים בדמותו של הערבי בתקופת שנות השלושים והארבעים • בימים שלפני קום המדינה • בסימטאותיה של ירושלים • בחוציתיה של יפו • בפרבריה של תל-אביב • בצפת ובטבריה • בכמה מכפרי

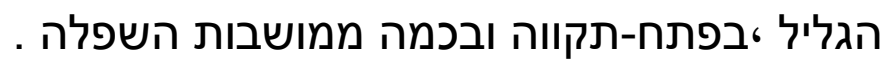

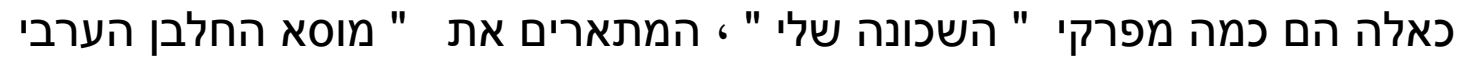

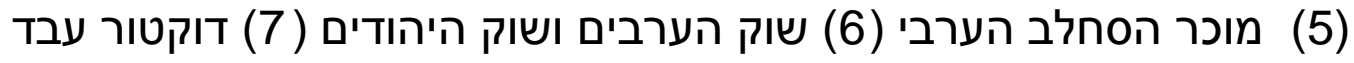

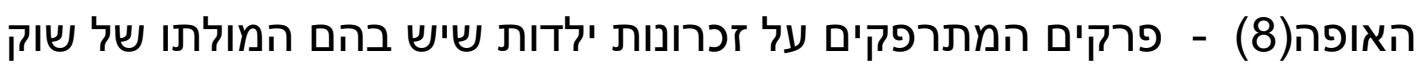

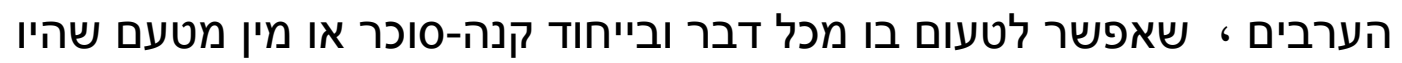

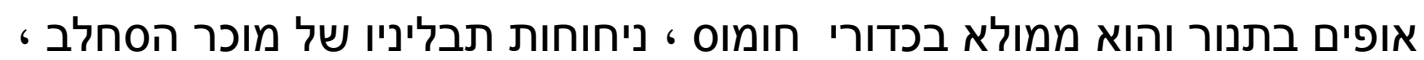

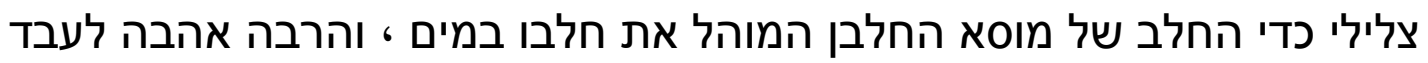
האופה היודע לחבוש רגל נקועה בעיסת בצע בה עירבב בצל קצוץ וזאת לאחר

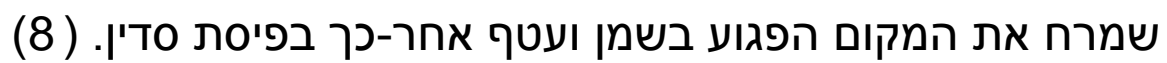

האווירה שופעת חום וזיקה שבלב • אך היא דוברת יותר לליבם של המבוגרים השומרים בנפש פינה חמה לזכרונות ילדות מאשר לילדים אשר קטר הטעי-הותי-הווי

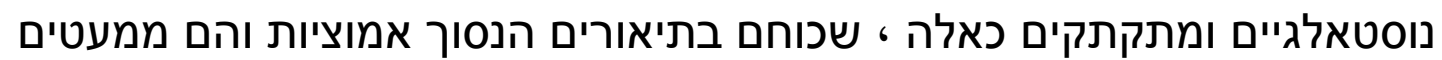

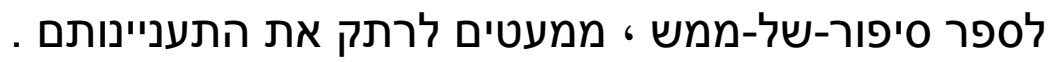

רוח נוסטאלגית מסויימת שפוכה אף על תיאורי אריות בירושלים של שמואל הופרט(9) אולם כאן • שלובים הדברים בסיפור-הרפתקה מסת מקורי הספוג

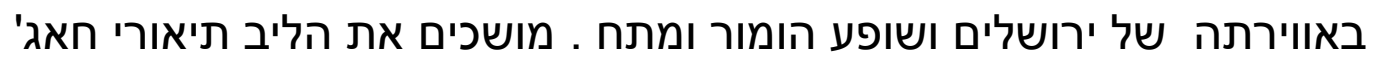

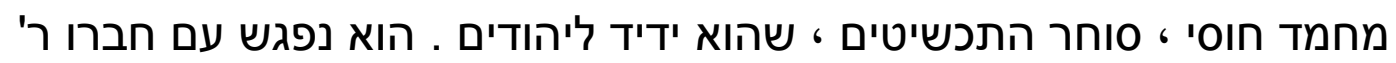
אברהם חסין על רקע איחודה מחדש של ירושלים אחרי מלחמת ששת-הימים : " " בסימטאות החרבות של הרובע היהודי פגש ר' אברהם ידיד ותיק • חאג' מחמוד

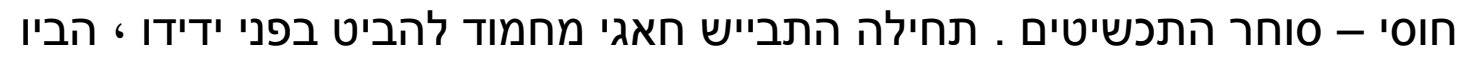




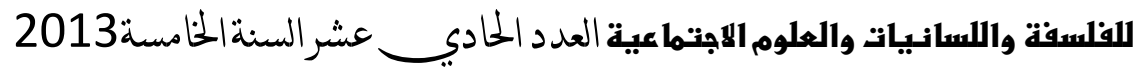

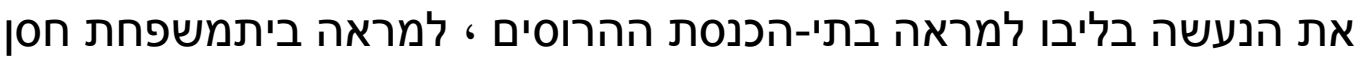

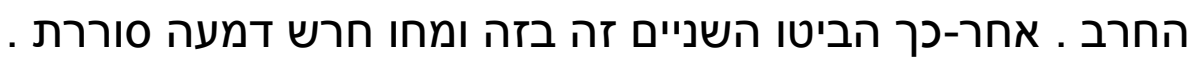

איש לא ראה אותם בצערם • בעלבונים . בלאמר מלה צעדו החג'וסוהמוכתר בסימטאות המוכרות לעבר ביתו של מחמוד ברובע המוסלמי " (10)

מחמוד חוסי ניסה לשמור על רהיטי משפחת חסין • שעשי שעבה את העיר העתיקה

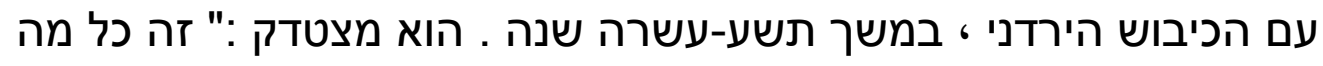

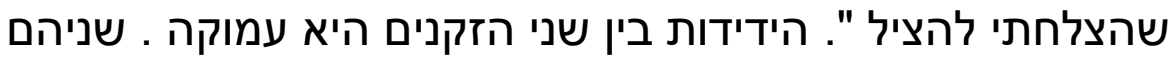

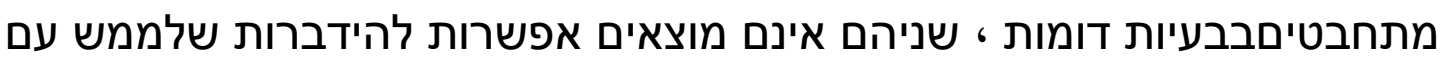

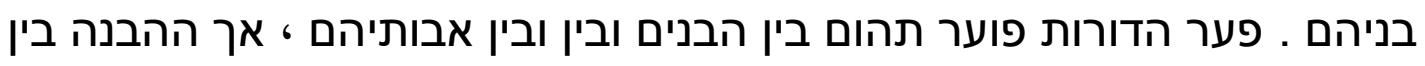

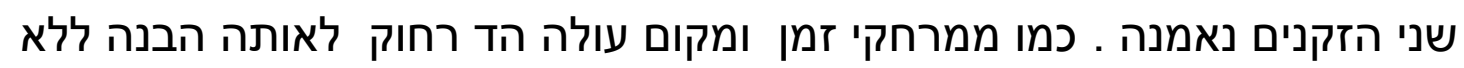

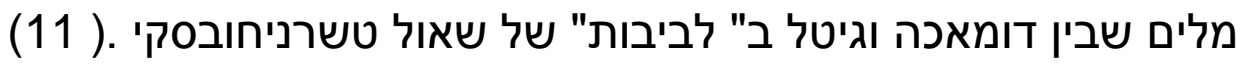

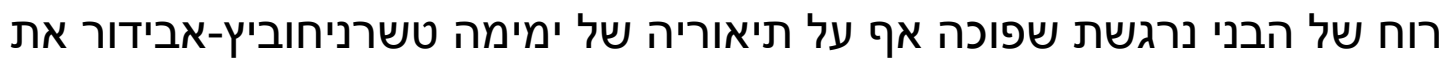

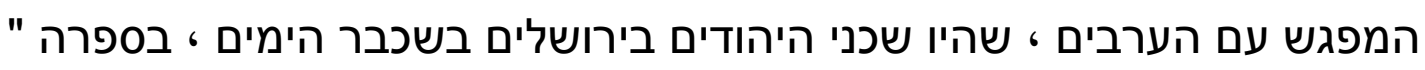

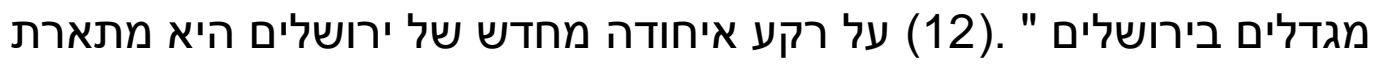

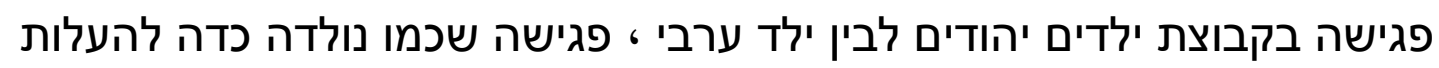

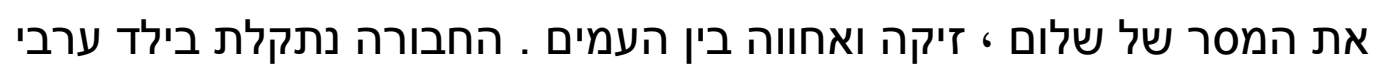

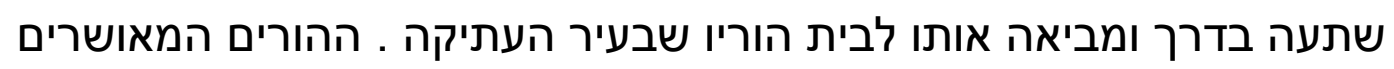

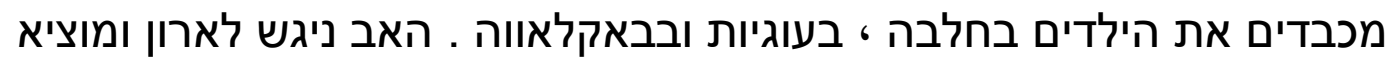

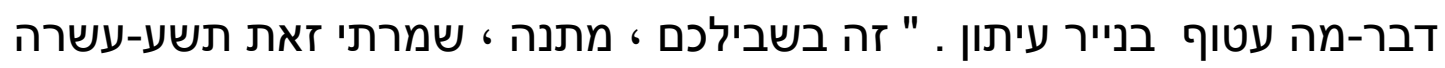

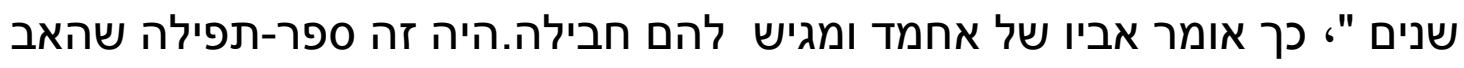

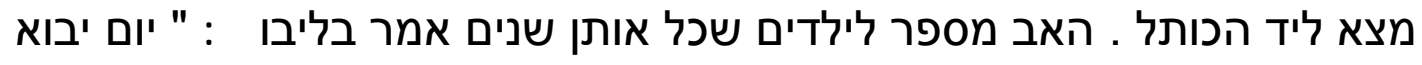

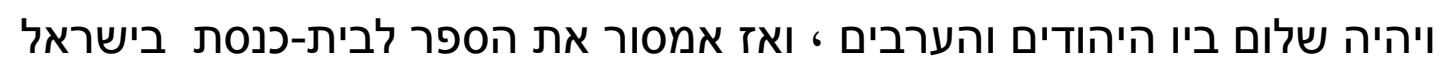

ההתרפקות הנוסטאלגית עלימי הייבוש הישן • החייאתם של יחסי שכנות טובה

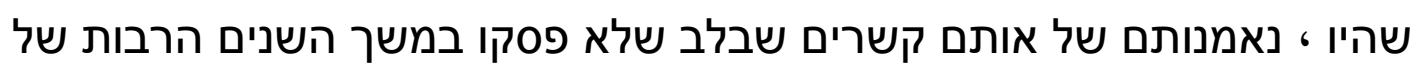

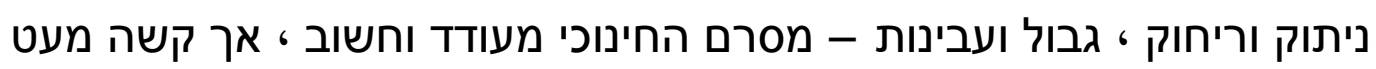

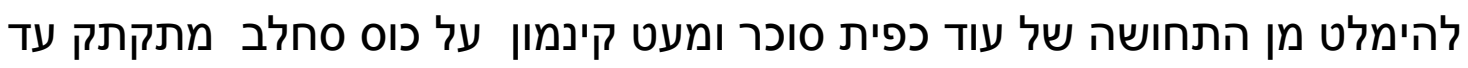


גדישה רבה מדי של צבעים נגלהגם בכמה מתיאוריהקשרים הצעירים למעוז

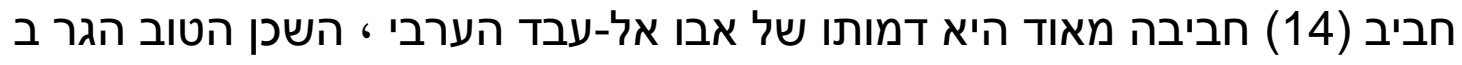

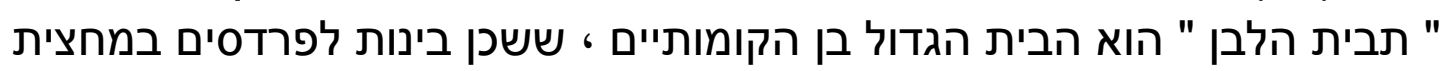

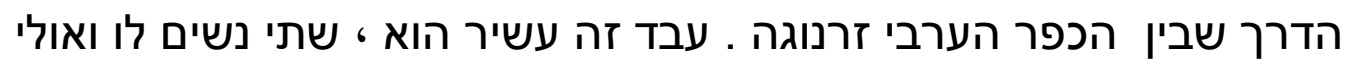
עשרים בנים ובנות הוא מכבד יהודים וחי עמהם בשלום . מדבר לא רק עברית •

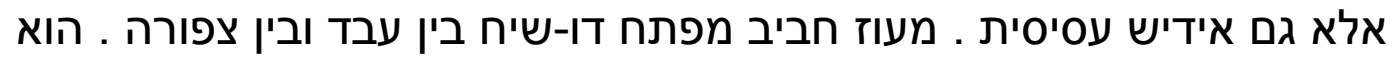
עוצר את חמורו ואומר לצפורה הנקרית בדרכו : " 'או' ، לא טוב לי על הלב בימים עים

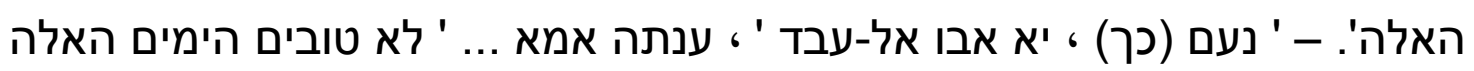

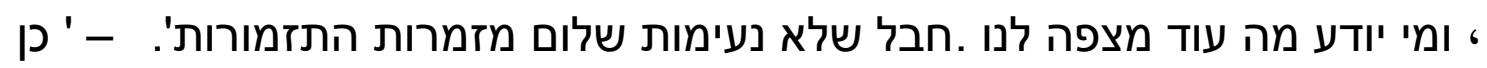

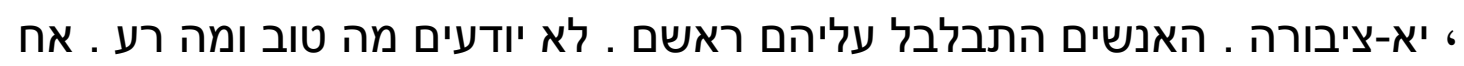

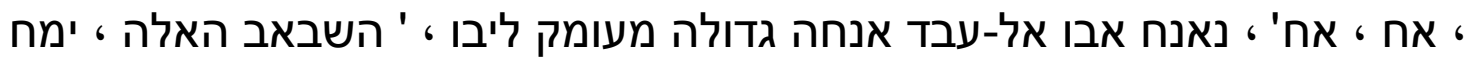

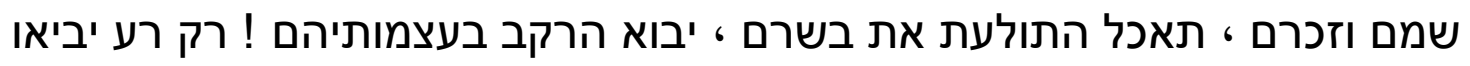

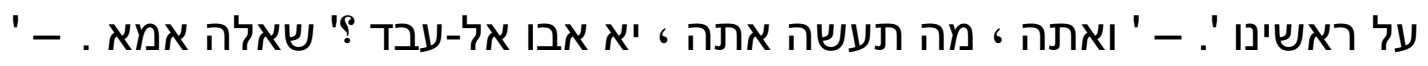

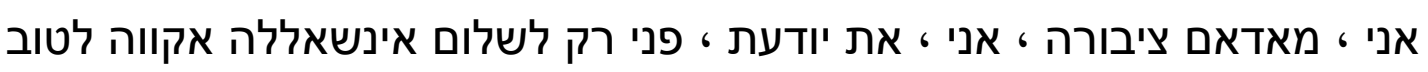

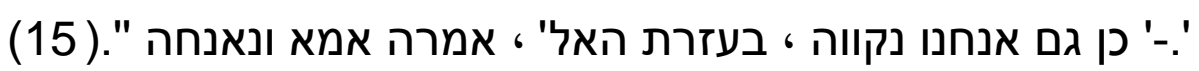

נאנחים ומשתפכים במליצות • ואמנם אין המליצה זרה לשיחה כזאת של אותם

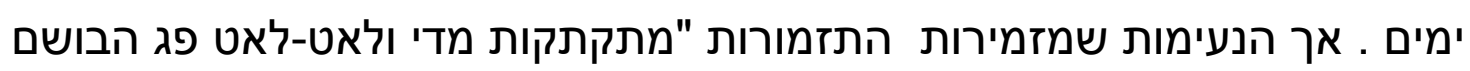
של אותה שיחה . פורצת המלחמה • הכפר של אבו אל-עבד נהרס . הילדים

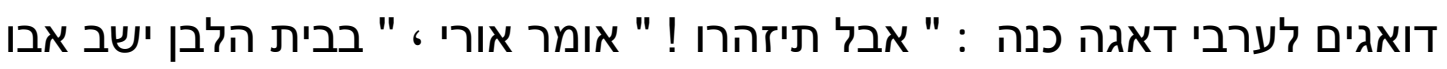
אל-עבד עם המשפחה שלו . הוא ערבי טוב ותמיד היה איתנו בידידות • אל תפגנעו

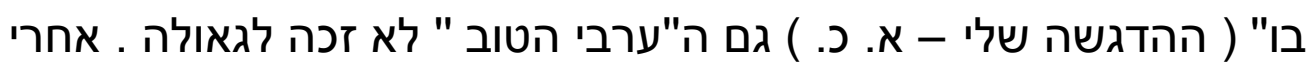

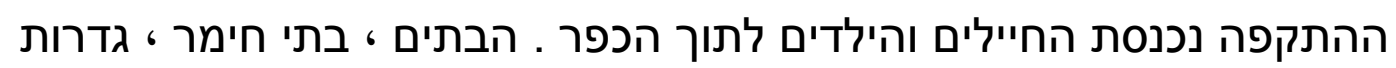
דוקרניות וקוצניות • תרנגולות מקרקרות מתרוצצות בחצרות • הרס ועזובה : "

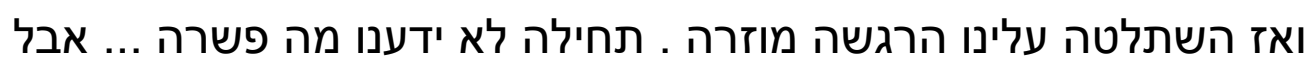

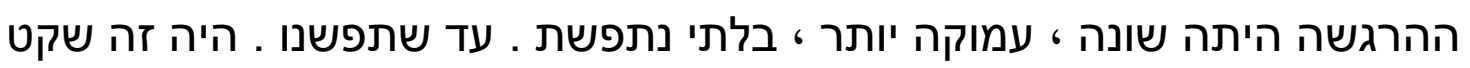

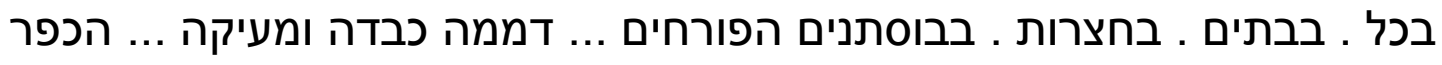

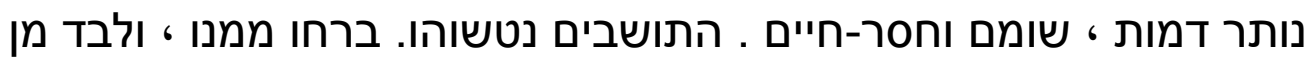

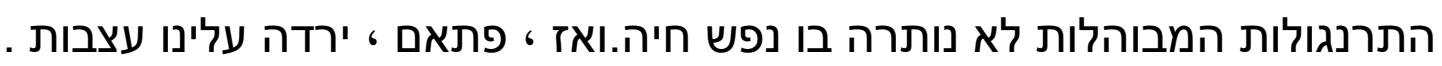

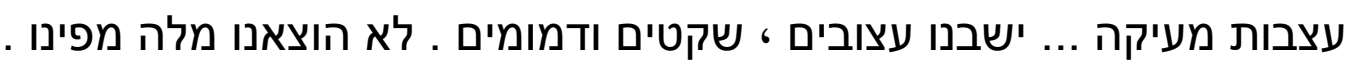

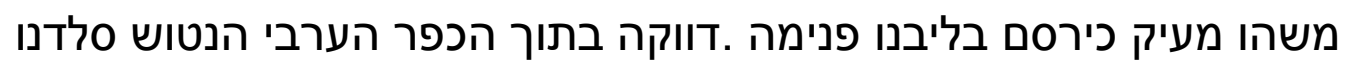

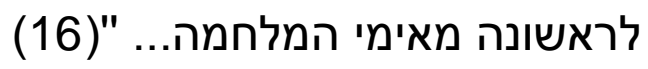




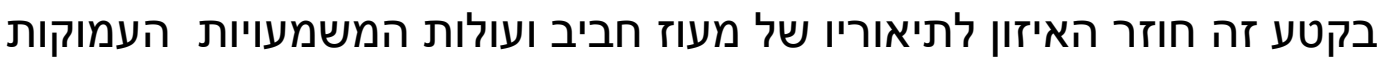

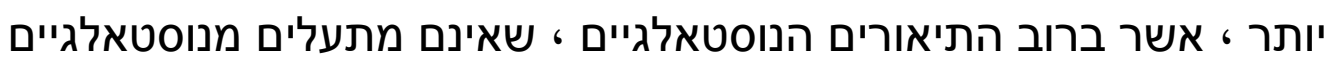
מילולית דברנית • אך הן מצליחוב התיאום להבקיע .

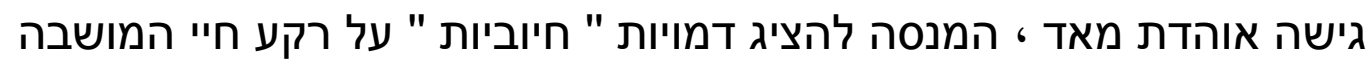

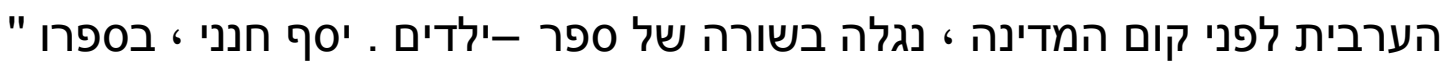

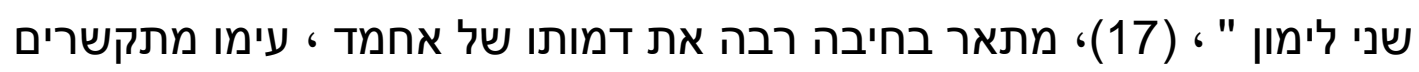

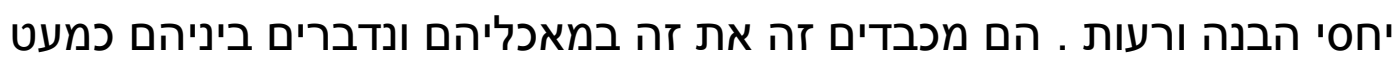

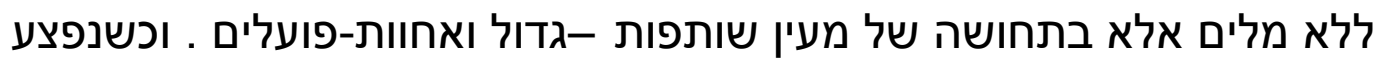

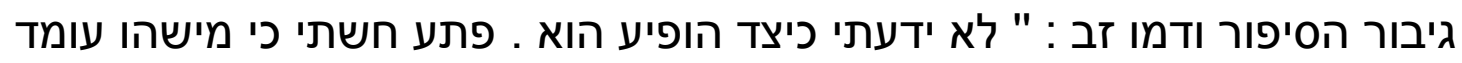

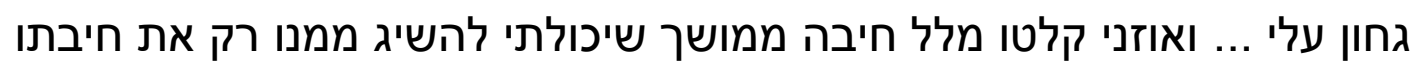

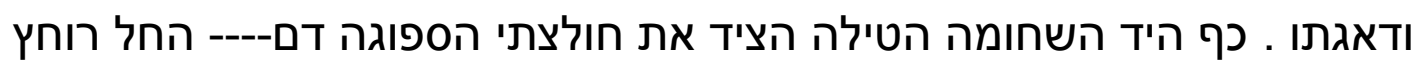

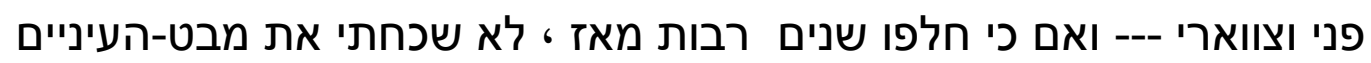

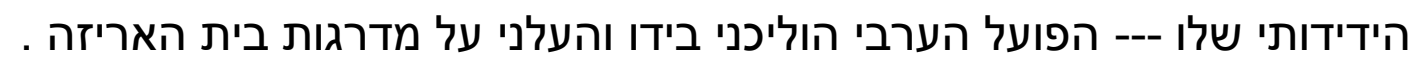

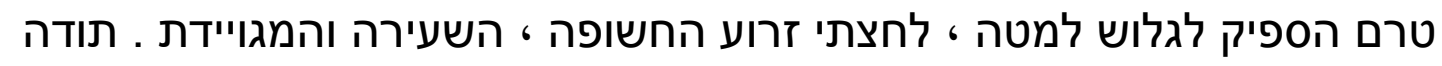

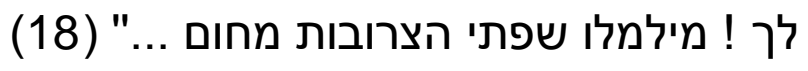

רוח טובה ואוהדת שפוכה על הסיפור "השקדיה על הגבול " בספרו של מרדכי

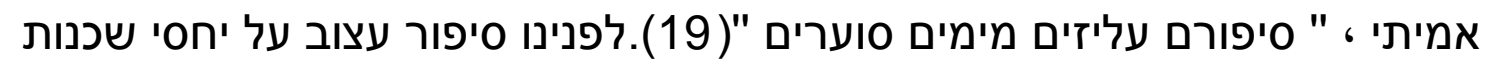

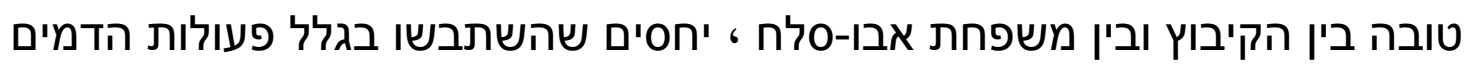
של כנופיות ערביות בתקוץיופת מלחמת אבו-סלחי השחרור.

האנגלים עוזבים את הארץ ולילדי הקבוץ נאמר כי מכאן ואילך הגבול חוצה בין

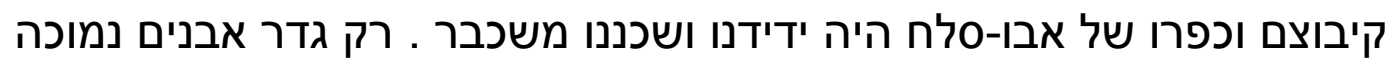

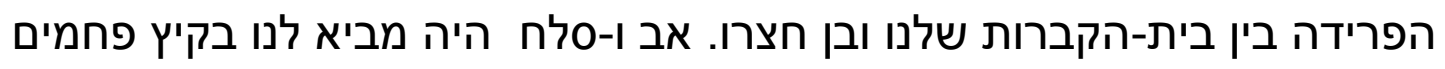

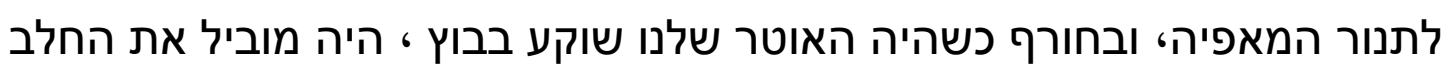

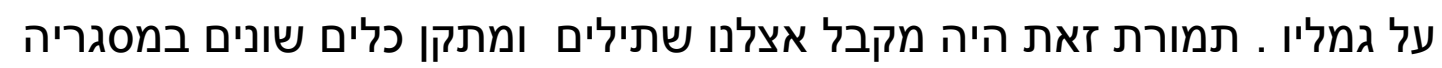

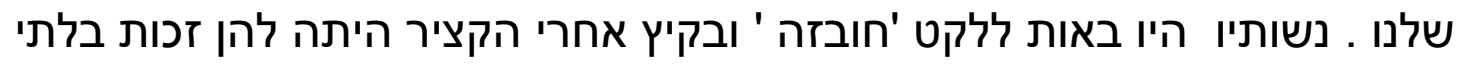

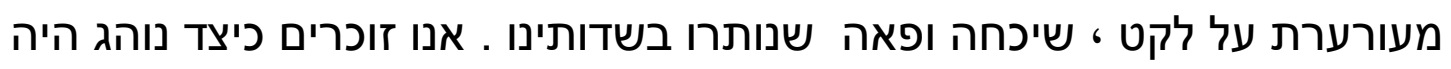

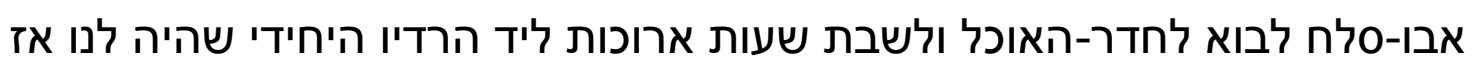

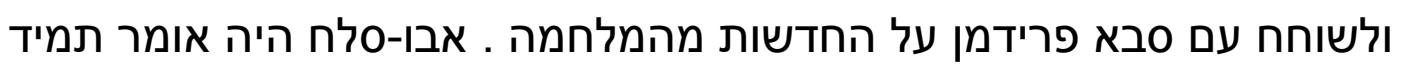
בעברית שלו : ' מלחמה לא טמובה על הובי '. וכנראה צדק "(20). 
המסקנות

מתוך הספרים שנבדקו ובהם נמצאו תיאורים של מרקם יחסים כלשהו בין ניחים

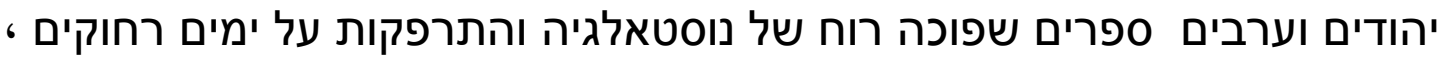

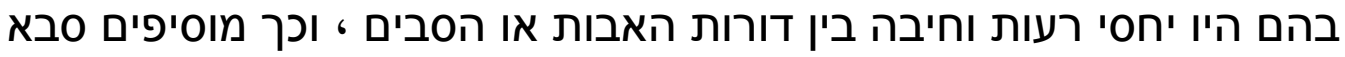

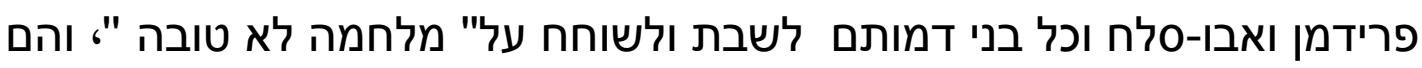
צודקים ! ומשמסתיימת הנוסטאלגיה החמימה יוצאים הבנים והנכדים אל מלחים המלחמות החדשות . המתימת

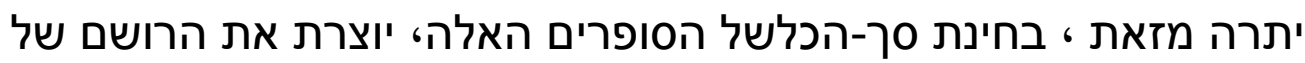

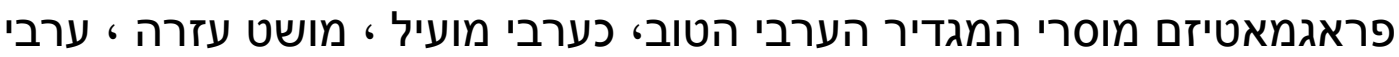
שאיננו רק ידיד אלא אף עוזי מיר יהודים בסביבתם ובשכונתם הטים

\section{הערות}

1. מנחים רוזנר ، ישראל וערב - יחסי עמים ויחסי אנוש בעיני שני הדורות

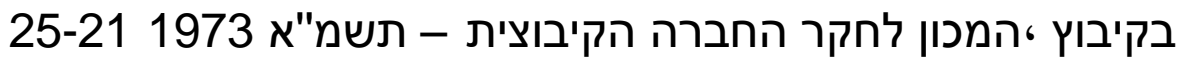

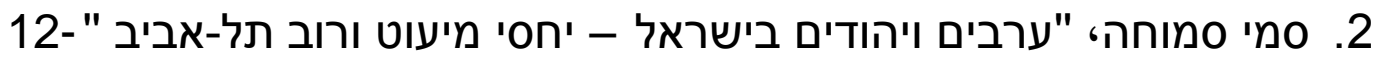

3. ישראלית פוקן، מוצאם של ערבייארץ- ישראל • תל-אביב، 1965، 45-43

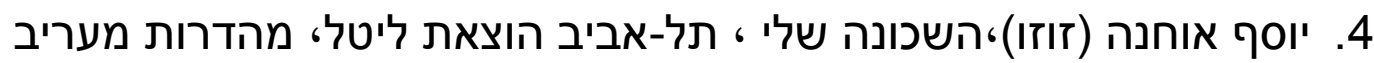

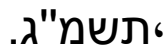

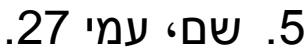

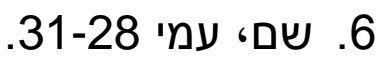

3 - 9.

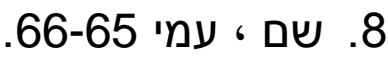

9. שמואל הופרט • אריות בירושלים ، רמת-גן : הוצאת מסדה ، 1973.

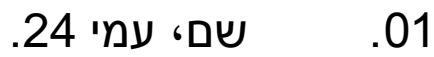

11.

$$
\text { מסה ، } 1968 .
$$

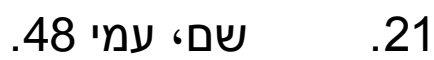

31 


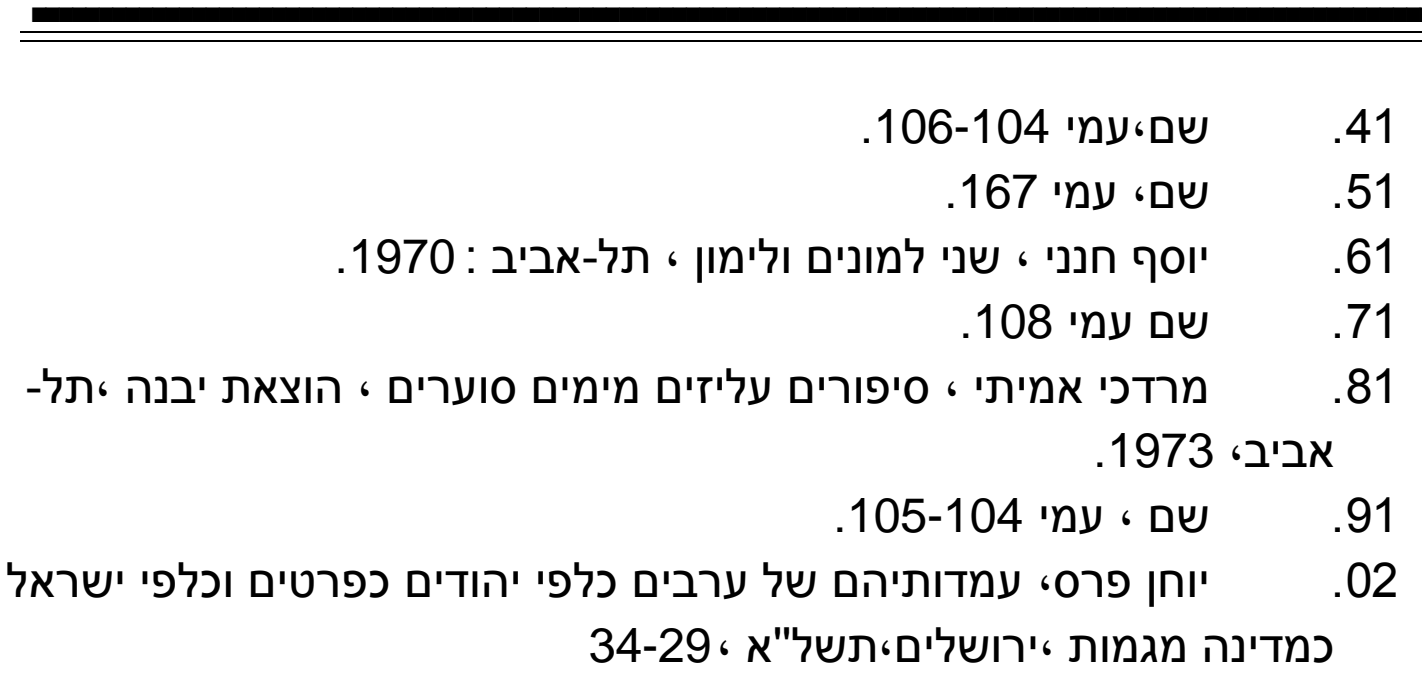

\section{המקורות}

1-ימימה טשרנוביץ-אבידור • מגדלים בירושלים • רמת-גן : הוצאת מסדה ،

1968

2-ישראלית פוקן، מוצאם של ערבייארץ- ישראל ، תל-אביב، 1965، 45-43 3-יוסף אוחנה (זוזו)•השכונה שלי ، תל-אביב הוצאת ליטלי מהדרות מעריב (תשמ"ג، 4- יוסף חנני ، שני למונים ולימון • תל-אביב : 1970. 5-יוחן פרס، עמדותיהם של ערבים כלפי יהודים כפרטים וכלפי ישראל כמדינה מגמות ירושלים‘תשל"א •34-29 6-מנחים רוזנר ، ישראל וערב - יחסי עמים ויחסי אנוש בעיני שני הדורות בקיבוץ

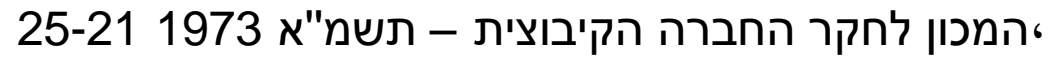
7-מעוז חביב • הקשרים הצעירים ، תל-אביב : הוצאת מ.מזרחי ، 1974 8-מרדכי אמיתי ، 0יפורים עליזים מימים סוערים ، הוצאת יבנה •תל-אביב، 1973 9-0מי oמוחה، "ערבים ויהודים בישראל - יחסי מיעוט ורוב תל-אביב "12-17 10-שמואל הופרט • אריות בירושלים ، רמת-גן : הוצאת מסדה ، 1973. 